\begin{tabular}{c} 
International Journal of Engineering \& Technology, $7(3)(2018) 1576-1580$ \\
International Journal of Engineering \& Technology \\
SPC \\
Website: $\begin{array}{c}\text { ww. sciencepubco.com/index.php/IJET } \\
\text { doi: } 10.14419 / \text { ijet.v7i3.12110 } \\
\text { Research paper }\end{array}$ \\
\hline
\end{tabular}

\title{
High-order thinking skill in contextual teaching and learning of mathematics based on lesson study for learning community
}

\author{
Hobri $^{1 *}$, Ice Septiawati ${ }^{2}$, Antonius Cahya Prihandoko ${ }^{1}$ \\ ${ }^{1}$ Postgraduate of Mathematics Education Department, University of Jember, Indonesia \\ ${ }^{2}$ Graduate Student, Mathematics Education Department, University of Jember, Indonesia \\ *Corresponding author E-mail: hobri.fkip@unej.ac.id
}

\begin{abstract}
This research aimed to develop Mathematics instructional instruments by using Contextual Teaching and Learning (CTL) Based on Lesson Study for Learning Community (LSLC) on "Sequence and Series" Learning Material for the tenth grade students of vocational school as well as to know its effect on the students' high-order thinking skill. The method used is mixed methods with concurrent triangulation strategy model namely research and development method with Thiagarajan model combined with quantitative method using non equivalent control group design quasi experimental pretest-posttest. The research subjects were the students of SMKN 1 Panji of Situbondo regency, from which two classes were chosen as research sample, class X Accounting 2 as the control class and class X Accounting 3 as the experimental class. High-order thinking skill is measured by using essay test. Assumption test of normality and homogeneity of variance was tested before analyzing the data. The result of the first test showed that the data were not normally distributed. Therefore, the data were ana-lyzed by using Mann-Whitney analysis. The research results showed that: (1) the instructional instruments resulted is valid, the implementa-tion of the instructional instruments is in practical and effective; (2) the significance value (2-tailed) is 0.000 ( $p<0.05)$, which indicated that the application of learning by using CTL Based on LSLC had a significant effect on the students' high-order thinking skill.
\end{abstract}

Keywords: Contextual Teaching and Learning (CTL); Lesson Study for Learning Community (LSLC); High-Order Thinking Skill.

\section{Introduction}

High-order thinking is an important component of $21^{\text {st }}$ century skills [1]. It is an ability of thinking critically, creatively, the ability of arguing, discussing, making decision and solving problems [1], [2]. In the range of cognitive skills, high-order thinking skill includes analyzing (C4), evaluating (C5), and creating (C6) [3]. This skill can be developed through mathematics since its learning objective is to encourage the students to become individuals who can think critically, creatively, logically and systematically in solving problems and also to equip the students with the skills required in the era of globalization [4].

One of the learning materials of Mathematics for the tenth grade students of vocational school which is related to the application of contextual problems and high-order thinking skill is "Sequence and Series" learning material. Based on the interview with the Mathematics teacher of that school, it was revealed that: (1) the students had difficulties in solving contextual problems, (2) the students had difficulties in finding the pattern of a numbers sequence, (3) the teacher just showed the formulas available on the book; hence, the students used to rote and memorize them, (4) the students' worksheet only consisted of many exercises, (5) the students tended to think individually, and did not care for their friends who felt difficult in learning, and (6) the students did not optimally work cooperatively in groups. Briefly, the problems emerged have not become meaningful knowledge gained by the students, the students' skill of high-order thinking has not been honed, there were also no collaboration among the students, and the students tended to think of themselves and ignored their friends around.

Contextual Teaching and Learning (CTL) is a learning approach where students learn to relate the learning materials with the real situation so that the knowledge they achieved may become meaningful. To be able to understand the knowledge and skill will lead to master both of them [5]. While lesson study for learning community (LSLC) is a type of current Lesson Study which uses collaborative learning and the concept of Learning Community [6], [7]. Besides, it is given jumping task in LSLC-based learning - a task with higher level than the curriculum demands for students who have higher skills than the averages to improve their high-order thinking.

Considering the issues explained above, it is deemed necessary to develop instructional instruments with CTL based on LSLC to improve the students' high-order thinking skill. This learning is carried out in several stages, they are: (1) Constructing, (2) Finding, (3) Authentic Assessment, (4) Modeling, (5) Reflection, and (6) Jumping Task. The series of stages are carried out in collaboration between teachers and teachers (plan, do, see), students and teachers, and among students, with a sense of mutual care and none of the students are neglected. Elements of high-order thinking skill are contained in the material as well as the questions presented.

This research is different from the preceding studies. The research that conducted by Andini, et al [8] aimed to describe the students' activities of using Problem-Based Learning (PBL) be oriented LSLC. Another research conducted by Eisuke Saito and Matthew Atencio [9] aimed to discuss the philosophical foundations of the 
LSLC, with a particular emphasis on the nature of social justice, especially on the critiques towards the neo-liberal reform agenda. Then, the research conducted by Mahbube Keihaniyan [10] aimed to see the relationship between collaborative learning and motivation. The research conducted by Lewy, et al [11] aimed to generate questions to measure valid and practical high-order thinking skill and to see the potential effects of those questions to measure highorder thinking skill towards the students' learning results.

\section{Research method}

The method used in this research is Mixed Methods with Concurrent Triangulation Strategy model, that is using R\&D with Thiagarajan model, and quantitative method using non equivalent control group design quasi experimental pretest-posttest which were done at the same time. Thiagarajan model consisted of four stages known as 4-D Model. Those stages are define, design, develop, and disseminate [12].

R\&D aimed to develop Mathematics instructional instruments in mathematics contextual teaching and learning based on LSLC. The instructional instruments referred in this study were: lesson plans, students' worksheets, and tests and also the research instruments including students' activities observation sheet, implementation of the instructional instruments, open class observation, and students response questionnaire. The instructional instruments and the instruments of the research could be used if they were valid. If they were not valid yet, they would be revised based on the suggestion and input given by the validators.

1) Qquantitative research, i.e quasi experimental research with non-equivalent control group design pretest-posttest is done. The research population is Class $\mathrm{X}$ students of SMKN (vocational school) 1 Panji Situbondo East Java Indonesia in 2017/2018. The technique that use in choosing sample is cluster random sampling technique, 2 classes randomly from the population. The Class X Accounting 3 is chosen as the experimental class which would be taught by using the instructional instruments using CTL based on LSLC. While Class X Accounting 2 would be taught as usual using conventional direct teaching and learning model (Direct Instruction). The data were collected through the implementation of tests and observations and continued with the assumption test of normality and homogeneity of variance. The normality test used Kolmogorov-Smirnov, while the homogeneity test used Levene's test with level of significance $0.05(\mathrm{P}<0.05)$ for each. If the data were normally distributed, t-test would be done, and if the data were not normally, non parametric test would be done.

\section{Results and discussion}

Before giving treatment to the experimental class and control class, the development of the instructional instruments including Lesson Plans, Students' Worksheet and Test was done. Those instructional instruments were the result of the collaboration of the mathematics teachers in which they had given some inputs based on their experiences while they were teaching mathematics, especially on the learning material of "Sequence and Series". While the test is used as pretest and posttest to measure the students' high-level ability in order to gain the data of high-order thinking skill improvement in control class and experimental class. In addition to the instructional instruments, validation was also done on the research instruments like the students' activities observation sheet, the observation of instructional instruments implementation, open class observation and the students' response questionnaire.

The process of validation is done by [3] validators, they are [2] lecturers of Mathematics Education Department and a practitioner. The validation result is presented on Fig. 1 and Fig. 2.

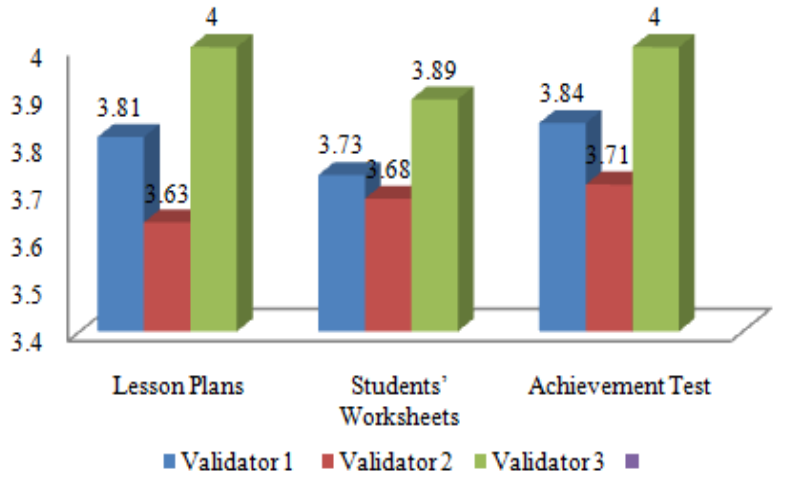

Fig. 1: Validation Result of Instructional Instruments.

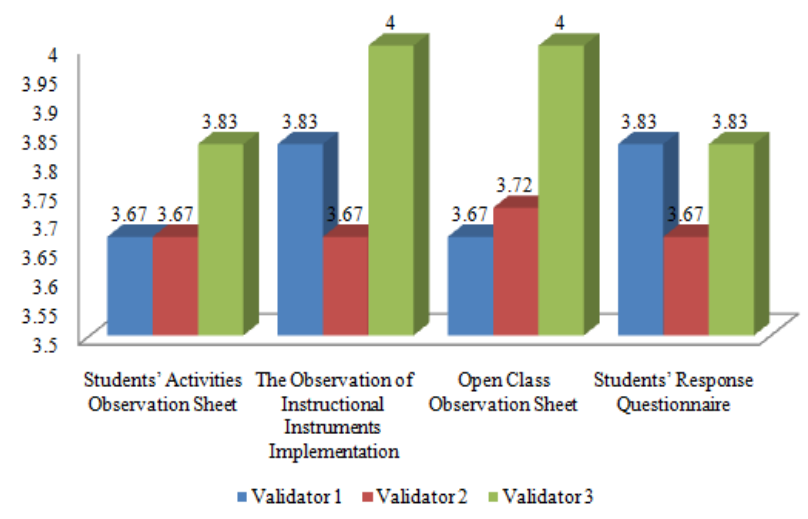

Fig. 2: Validation Result of Research Instruments.

The next stage is "Do". This research was conducted in [7] meetings [5] meetings for implementing the treatment, the first meeting for giving the pretest and the last meeting for giving the posttest). The same meetings done towards the control class which used direct instruction-learning model.

In the first meeting, the students were given a pretest consisting of [5] questions in 90 minutes. The result of this pretest is done to measure the students' high-order thinking skill before the implementation of the learning. The result of the pretest is presented in Table 1.

Table 1: The Students' High-Order Thinking Skill Based on the Pretest

\begin{tabular}{lllll}
\hline Class & $\begin{array}{l}\text { Highest } \\
\text { Score }\end{array}$ & $\begin{array}{l}\text { Lowest } \\
\text { Score }\end{array}$ & $\begin{array}{l}\text { Aver- } \\
\text { age }\end{array}$ & $\begin{array}{l}\text { Deviation } \\
\text { Std. }\end{array}$ \\
\hline Experi- & 60 & 25 & 33 & 2.007 \\
mental & 60 & 25 & 35 & 1.903 \\
Control & 60 & & & \\
\hline
\end{tabular}

The treatment of CTL Based on LSLC for the experimental class is done in the second meeting until the six ${ }^{\text {th }}$ meeting. The learning activities were done in collaboration among the students by making groups by themselves which consisted of 4 students for each. It is carried out in some stages namely: (a) constructing, (b) finding, (c) assessment, [d] presentation, and (e) reflection. While in control class, the students were taught using conventional teaching and learning model, Direct Instruction, where the teacher played role as the center of learning in serving the material and giving guided exercises.

In constructing and finding stages, students were directed to think individually at first and then to collaborate with friends in group without anyone neglected (caring community). In LSLC-Based learning, it is assumed that every student is accepted and cared for whatever their circumstances, beliefs and weaknesses are [9]. Similarly in assessment stage, the students were served with some exercises with high-order thinking level, and the activities were done collaboratively in caring community. It is in line with the opinion stated by Masaki Sato [6], [13] that the children's social interaction ability developed first and then followed by the development of academic ability in each child. Teachers as the facilitator should give scaffolding to the groups who need it. 
In experimental class, the students discussed, asked each other and the feel of caring grew among friends. The students' activities of asking and explaining in groups were presented on the following figure (it was taken from one of the groups as the sample).

Meeting-1

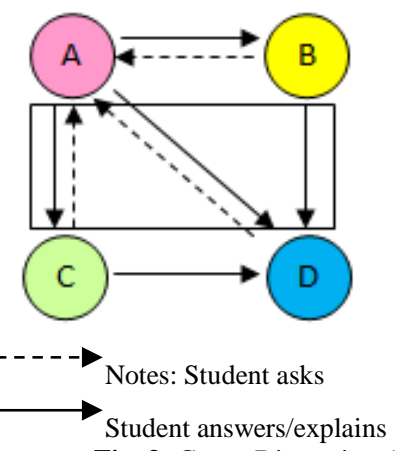

Fig. 3: Group Discussion Activity in Experimental Class.

The group discussion in the experimental class ran well. Student A gave explanation to all the group members. In this meeting, the questions were addressed to Student A only. However, Student B and Student $C$ helped to give explanation to Student D. In the next meeting, the group members agreed to exchange their seat positions. Student $\mathrm{D}$ who is less active and did not really understand the material sat beside Student A who is active and understood the material well. This condition indicated that the students had been able to collaborate and build caring community. It is proven by their high sense of care among friends [6], [7].

Meanwhile, the group discussion that occurred in the control class is presented on the following figure.

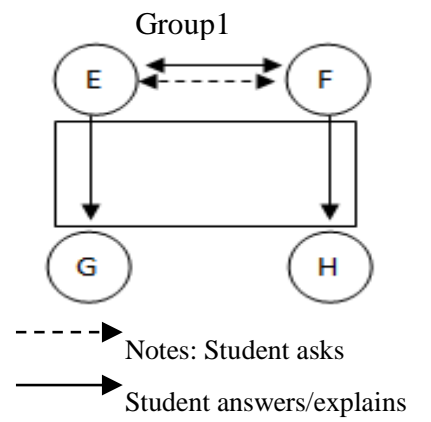

Fig. 4: Group Discussion Activity in Control Class.

In Group 1, the group discussion only occurred on Student E and Student F. Student G and Student H did not understand the material and did not ask the other friends who had understood. Similar condition happened in group 2, where Student K provided answers for all the other group members without giving explanation. The other members just copied the answers without understanding the meanings. Overall, the group discussions that occurred in control class just aimed to answer the problems given without caring whether all the members of the group had understood or not. The goal of the group making is merely to achieve a high score. This neglected the meaning of knowledge itself. Unlike the discussions in experimental class, there were no exchanges of seat position in control class.

Generally, based on the observation result of students' engagement including the activity of asking, arguing, doing, presenting and responding to the group discussion in experimental class, it showed that most of the students were active in the teaching and learning process. From 36 students of the experimental class, 32 students (89\%) belonged to active category and the other 4 students $(11 \%)$ were less/not active. Conversely, a different condition is showed in the control class in which from 36 students of the class, there were only 15 students $(42 \%)$ belonged to active students and 21 students $(58 \%)$ belonged to less/not active students. Therefore, it can be con- cluded that most of the students were active while joining Mathematics lesson by using CTL based on LSLC. The research findings were in line with those in study by Siska Ari Andini, et al [8]. This similarity pertained to the increase in students' activity upon taking part in the instructional activity driven by Problem Based Learning be oriented LSLC.

In the third and the fifth meetings, open classes were conducted and attended by 12 teachers from all subjects of SMKN 1 Panji Situbondo. Open class is one of the activities of LSLC which is continued by reflection of the students' activities observation result. Reflection is the "see" stage in LSLC which focused on how the students learn, while the observation on how the teacher teach as well as the learning material mastery would be given a very small percentage. After attending the open class activity, some teachers of different subjects were interested to apply LSLC in their own teaching classes. They knew that the students in experimental class collaborated actively, completed by their high sense of caring among friends in their groups. High scores did not become their main orientation but a bonus. The students' main goal in CTL based on LSLC is to gain meaningful knowledge [5]. The students' engagement, creativity, ability of arguing, discussing, making decision, and solving problem were well honed in this learning. Therefore, the teachers who attended open class positively thought that this learning could give a significant effect towards the students' highorder thinking skill.

Posttest is conducted in the last meeting to know the students' highorder thinking skill after joining the learning process. The result of the posttest is presented in Table 2 .

Table 2: Sstudents' High-Order Thinking Skill Based on the Posttest

\begin{tabular}{llllll}
\hline Class & $\begin{array}{l}\text { Highest } \\
\text { Score }\end{array}$ & $\begin{array}{l}\text { Lowest } \\
\text { Score }\end{array}$ & $\begin{array}{l}\text { Ave- } \\
\text { rage }\end{array}$ & $\begin{array}{l}\text { Dev. } \\
\text { Std. }\end{array}$ & $\begin{array}{l}\text { Percentage of } \\
\text { Classical Com- } \\
\text { pleteness }\end{array}$ \\
\hline Exp. & 95 & 60 & 71 & 3.328 & $78 \%$ \\
Cont. & 90 & 40 & 57 & 2.986 & $42 \%$ \\
\hline
\end{tabular}

The data analysis to know the effect of CTL based on LSLC. on the students' high-order thinking skill is begun using prerequisite test. It is the first step that should be done before doing hypothesis test covering normality test and homogeneity test. Normality test using Kolmogorov-Smirnov statistics is summarized in Table 3.

Table 3: Normality Test (Kolmogorov-Smirnov)

\begin{tabular}{lllll}
\hline Class & \multicolumn{1}{l}{ Kolmogorov-Smirnov } & & \\
\hline \multirow{3}{*}{ Pre-Test } & & Statistics & df & Sig. \\
& Experimental & .277 & 36 & .000 \\
Post-Test & Control & .213 & 36 & .000 \\
& Experimental & .159 & 36 & .021 \\
& Control & .239 & 36 & .000 \\
\hline
\end{tabular}

The data originated from the normally distributed populationif the probability value ( $p$-value) is bigger than the significance value of 0.05 . It is known that the pretest significance value of the students' high-order thinking skill in both classes is sig $=0.000$, while the posttest significance value in experimental class is sig $=0.021$ and in control class is sig $=0.000$. So, it could be concluded that the data of pretest and posttest in both classes were not normally distributed. Therefore, the data is analyzed by non parametric test, i.e Mann-Whitney test.

The difference of high-order thinking skill in both classes indicated value sig. $0.000(\mathrm{p}<0.05)$, so it could be summarized that there is a difference of high-order thinking skill between the control class which used conventional teaching and learning and the experimental class which used CTL based on LSLC. The average improvement of each aspect of high-order thinking skill in experimental class and control class is presented in Fig. 4.

Table 4: The Analysis of Mann-Whitney U Test

\begin{tabular}{ll}
\hline & High-order Thinking Skill Improvement \\
\hline Mann-Whitney U & 155,500 \\
Wilcoxon W & 821,500 \\
Z & -5.603 \\
Asymp. Sig. (2-tailed) & .000 \\
\hline
\end{tabular}


The average improvement score of high-order thinking skill on each aspect appeared to be very significant in experimental class. There is also average improvement occurred in control class but it is not bigger than what is occurred in experimental class.

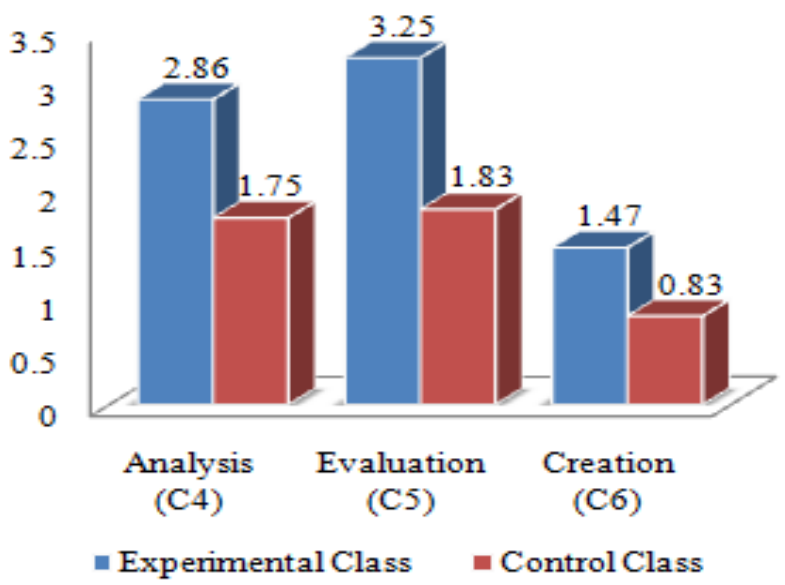

Fig. 5: Average Improvement of High-Order Thinking Skill Aspects.

From Fig. 5 above, the average improvement score of high-order thinking skill on each aspect appeared to be very significant in experimental class. There was also average improvement occurred in control class but it was not bigger than what was occurred in experimental class.

In this research, the indicators for measuring the students' high-order thinking skill referred to the statement of Krathwol [14]. In Fig. 6 , it was presented the student's answer on the analysis level (C4). That student had showed the analytical ability by revealing three indicators [14].

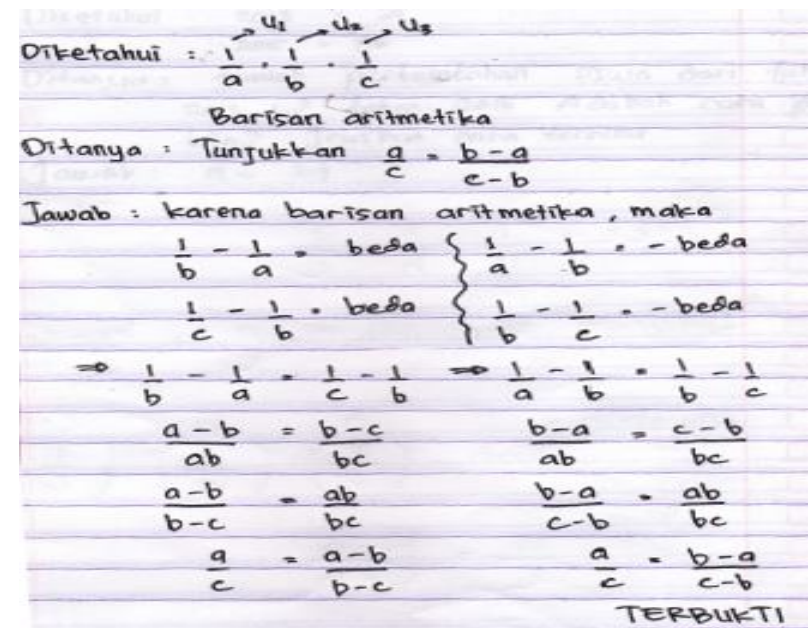

Fig. 6: The Answer of the Student Who Mastered Analytical Ability.

Notes:

Indikator1: Identifying or formulating the question

Indicator 2: Being able to recognize and distinguish the factor which become the cause and effect of a complicated scenario

Indicator 3: Analyzing the information obtained from structuring the information so be smaller parts in order to recognize the pattern of the relationship

The student with low-level thinking skill had not been able to show the three analytical abilities. One of their answers was presented in Fig. 7.
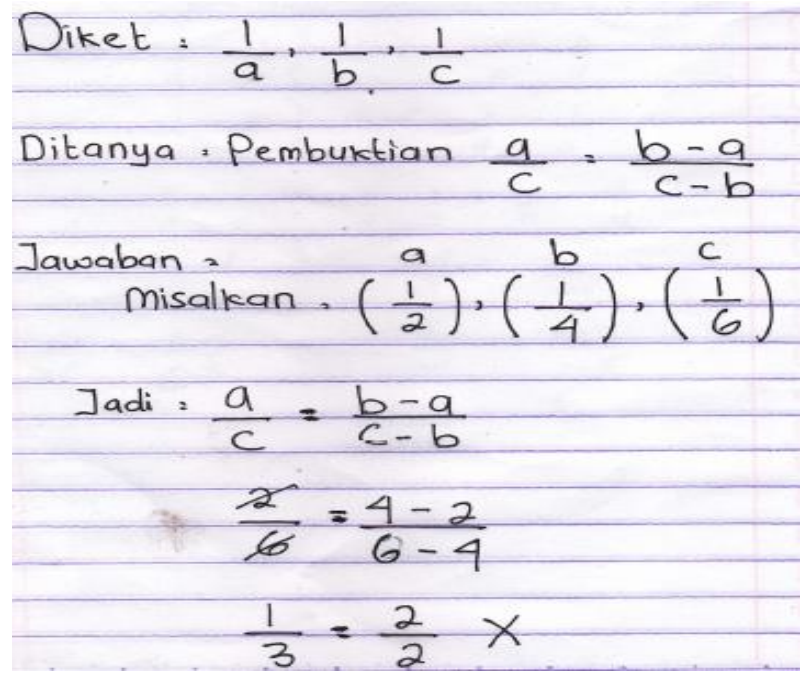

Fig. 7: The Answer of the Student with Low-Level Thinking Skill on Analysis Level.

Here is the interview result between the teacher and the student about his/her answers of analysis level question.

Teacher: Do you understand what is meant by arithmetic sequence? Student: Yes, Ma'am. It is the sequence of numbers with the same number of difference.

Teacher: Can you explain what the number of difference means? Student: The adjacent numbers are added of subtracted by the same number, Ma'am.

Teacher: a, b, c have the same number of difference. Then, why do you answer $\mathrm{a}=\frac{1}{2}, \mathrm{~b}=\frac{1}{4}, \mathrm{c}=\frac{1}{6}$ ?

Student: Because the number of difference between [2], [4], and [6] is [2], Ma'am.

Teacher: Are $\frac{1}{2}, \frac{1}{4}$ and $\frac{1}{6}$ only different by [2]? Count it again!

(The student seemed to be confused and tried to count it again).

Students: I think that my answer is wrong, Ma'am. Those numbers have different number of difference.

Thus, it could be concluded that the students above still did not have the ability up to the analysis level. They did not recognize yet about arithmetic sequence deeply, so that they failed to find the factor/s that could be the cause of an arithmetic sequence in series in which between one rate and another is only marked by a number of difference with the same value. This is kind of information that should be described or structured by the students in order to know the relationship or the pattern would be formed so that they could prove the equation given in the task.

At evaluation level, the students were expected to be able to judge on two installments (A and B) offered by Mr. Adi. Both installments formed sequence of numbers in which the first rate and the number of difference of each sequence were different. The students were asked to evaluate the accuracy of Mr. Adi's choice. The students who had reached high-order thinking skill were able to use the suitable criteria or standard that is using arithmetic series in order to ensure the benefit or effective value of the two offers. Then, the conclusion that could be drawn is to deny Mr. Adi's choice for offer A because after doing evaluation, offer B is more beneficial for him. While the students who had not been at evaluation level gave judgment without using the suitable criteria in order to ensure the benefit or effective value of the two offers. In other words, they did not do any test to gain the answer so that the judgment they gave did not have accurate basis and reason.

Moreover, the students who had high-order thinking skill and cognitive skill at creation level would fulfill the indicators: (1) Generalizing an idea or point of view of something, (2) Designing a way to solve problems, (3) Organizing elements or parts become a new structure [14].

From the data explained above, the effectiveness test of Mathematics learning using CTL based on LSLC had been fulfilled. It showed that: (1) the result of high-order thinking skill test with classical completeness percentage is $78 \%>75 \%$, (2) the students' activeness 
while joining the lesson is very high, (3) there is a significant improvement of average score of high-order thinking skill in experimental class.

The observation result indicated that the implementation of the learning ran well with average of 3.8 of each aspect. The result of the students' response questionnaire showed that more than $85 \%$ students gave positive responses to the instructional instruments and the implementation of CTL based on LSLC. Therefore, the practicality test for the instructional instruments could fulfill the criteria namely: (1) the learning implementation belonged to good category and (2) the students responded positively to the instructional instruments and the implementation of CTL Based on LSLC.

\section{Conclusion}

The results of the research showed that learning Mathematics by using Lesson Study for Learning Community-Based Contextual Teaching and Learning on "Sequence and Series" learning material for the tenth grade students of vocational school is valid, effective and practical. It also had a significant effect on the students' highorder thinking skill. Both the students who were joining the lesson and the teachers who were attending the open class gave positive responses on CTL Based on LSLC.

For further studies, a similar research can be tested on the students with different level of education, different learning material, and also different learning model without losing the main characteristic of this research, Lesson Study for Learning Community (LSLC).

\section{Acknowledgement}

The writer would like to thank Faculty of Teacher Training and Education of University of Jember for the support provided for the completion of the writing of this journal.

\section{References}

[1] Zohar, A., and Cohen, A. (2016). "Large scale implementation of higher order thinking (HOT) in civic education: the interplay of policy, politics, pedagogical leadership and detailed pedagogical planning". Thinking Skills and Creativity. http://dx.doi.org/ 10.1016/j.tsc.2016.05.003. last visit on May 10, 2017.

[2] McMahon, G. P., (2007). Getting the HOTS with what is in the box: Developing higher order thinking skills within a technology-rich learning environment. Thesis presented for the Degree of Doctor of Philosophy of Curtin University of Technology.

[3] Pohl. (2000). Learning to Think, Thinking to Learn: available a www.purdue.edu/geri. . last visit on October 1, 2017.

[4] Widdiharto, Rahmadi. (2004). Models of Mathematics Learning. Yogyakarta: PPPG Dirjen Dikdasmen Matematika.

[5] Johnson,E. B. (2007). Contextual Teaching and Learning. Bandung: Mizan Learning Center.

[6] Hobri. (2016). "LSLC: Review of Short Term on Lesson Study V in Japan". Proceeding of Conference, 12-21, 28 May. Pamekasan : Madura University.

[7] Mustadi, A. (2014). "Fundamental School Reform through Lesson Study for Learning Community (LSLC): a Study of Collaborative Learning in Indonesia and Japan". Proceeding International Conference on Fundamentals and Implementation of Education (ICFIE). p. $87-95$.

[8] Andini, S.A., Susanto., Hobri. (2017). "Students' Activity in Problem-Based Learning (PBL) Math Classroom be Oriented Lesson Study for Learning Community (LSLC)". International Journal of Advanced Research (IJAR). 5(9): 1395-1400 https://doi.org/10.21474/IJAR01/5458.

[9] Saito, E and Atencio, M. (2014). "LSLC: conceptualising teachers' practices within a social justice perspective", Discourse: Studies in the Cultural Politics of Education,. Las visit on November 3, 2017. https://doi.org/10.1080/01596306.2014.968095.

[10] Keihaniyan, M. (2013). "Collaborative Learning and Motivation". International Journal of Advanced Research.I(10): 613-621

[11] Lewy, Zulkardi, and N. Aisyah. (2009). "The development of test to measure high level thinking". Journal of mathematics education. 3(2): 14-28.
[12] Hobri. (2010). the Methology of Research and Development. Jember Pena Salsabila.

[13] Arends, R. (2012). Learning to Teach. Ninth edition. New York: McGraww-Hill.

[14] Krathwohl, D. R. (2002). "A revision of Bloom's Taxonomy: An overview". Theory into Practice, 41(4), 212-218. https://doi.org/10.1207/s15430421tip4104_2. 